\title{
Resveratrol enhances apoptosis induced by the heterocyclic aromatic amines in p53-wt LoVo cells, but not in p53-deficient HaCaT cells
}

\author{
Katarzyna Kurylowicz#, Agnieszka Cierniak²\#, Ewelina Madej¹, Lukasz Skalniak³ and \\ Agnieszka Wolnicka-Głubisz ${ }^{10}$
}

'Department of Biophysics, Faculty of Biochemistry, Biophysics and Biotechnology, Jagiellonian University, Kraków, Poland; 2Department of Medicine and Health Sciences, Andrzej Frycz Modrzewski University, Kraków, Poland; 3Faculty of Chemistry, Jagiellonian University, Kraków, Poland

In the present study, we investigated the influence of resveratrol on PhIP treated human colon cancer cells and compared the effect to $\mathrm{HaCaT}$ cells considered as normal, human keratinocytes. Our results show that resveratrol decreases DNA damage induced by PhIP in both cell types, it increases the sensitivity of LoVo cells to apoptosis and has no effect on PhIP-treated HaCaT cells. We confirm that PhIP-induced apoptosis is p53 and caspase 3/7 dependent. Interestingly, normal cells such as HaCaT are more resistant to PhIP treatment.

Key words: colon cancer, PhIP, resveratrol, DNA damage, apoptosis, p53

Received: 02 September, 2020; revised: 25 September, 2020; accepted: 28 September, 2020; available on-line: 27 October, 2020

$\square$ e-mail: a.wolnicka-glubisz@uj.edu.pl

\#KK and $\mathrm{AC}$ contributed equally

Abbreviations: CRA, colorectal adenomas; $C R C$, precursors of colorectal cancer; PhIP-2, amino-1-methyl-6-phenylimidazo[4,5-b]pyridine; Res, resveratrol (3,5,4'-trihydroxystilbenes)

\section{INTRODUCTION}

Colorectal carcinoma (CRC) is the fourth most commonly diagnosed cancer and the third most likely to cause death in the World. Diet plays an important role in etiology of colon cancer. Many studies indicate that high overall consumption of red and processed meat increases the risk of colorectal cancer (Zandonai et al., 2012; Kim et al., 2011; Chan et al., 2011). It is estimated that $70 \%$ of CRC cases could be avoided due to diet modifications. Based on the analysis of the available data, in 2007 the World Cancer Research Fund recommended the consumption of no more than $300 \mathrm{~g}$ of unprocessed red meat (beef, pork, goat, lamb) per week (World Cancer Research Fund/American Institute for Cancer Research, 2007). Research suggests that the relationship between meat consumption and the risk of colorectal cancer may be associated with the process of its preparation because higher risk of colorectal cancer is observed in people who consume meat cooked at high temperatures for a long time (Sinha et al., 1999). This suggests the role of substances that are created during grilling or frying meat, meat products and fish, among other HCA - heterocyclic aromatic amines such as PhIP (2amino-3-methyl-3H-imidazo[4,5-f]quinoline) (Sugimura, 1997; Robbana-Barnat et al., 1996). The amount of PhIP formed depends on the type of food as well as the method, temperature and processing time (Skog et al., 1995). The total amount of HCA formed is estimated to be $10.89 \mathrm{ng}$ per $1 \mathrm{~g}$ of heat-treated meat at $195^{\circ} \mathrm{C}$ (Puangsombat et al., 2012). In much smaller quantities, HCA are also present in environmental pollution and tobacco smoke (Manabe et al., 1991). There are many reports of the dietary effect of PhIP on increasing the incidence of human colorectal adenoma (Rohrmann et al., 2009), renal cells carcinoma (Daniel et al., 2012), rectal cancer (Ferrucci et al., 2012), and esophagus cancer (Cross et al., 2011). PhIP in a native form, delivered with food, does not have any carcinogenic effect. However, the metabolism of this substance which occurs in the human body, increases its toxicity. PhIP metabolism occurs via the liver CYP1A2, and via CYP1A1/1B1 in other tissues. Conjugation with glucuronide by means of UGT (UDP-glucuronyltransferase) enzymes or reduction by NADPH reductase results in detoxification, while the enzyme reaction from SULT groups (NAT) (N-acetyltransferases) leads to the formation of $\mathrm{N}$-sulfonyloxy$\mathrm{PhIP}$ and N-acetoxy-PhIP which are very reactive and toxic compounds that form adducts with DNA, which may lead to impairment of the replication process, point mutations and chromosomal aberrations (Holme et al., 1989). Also, the results of the last meta-analysis suggest that there is a positive association of HCAs mutagenicity index with the risk of colorectal adenomas (CRA) which are precursors of CRC. Additionally, this dose-response analyses showed an increased risk for CRA in the case of PhIP and mutagenicity index (Martínez Góngora et al., 2019). One can try to limit the amount of PhIP consumed by changing the eating habits, but it is difficult to eliminate PhIP completely. Fortunately, the diet may also abound in compounds with opposite beneficial effects, referred to as nutraceuticals, which currently include many substances, such as cruciferous indoles, carrot carotenoids, black and green tea polyphenols, curcumin or resveratrol from red wine (De Silva \& Lanerolle, 2011).

Resveratrol (3,5,4'-trihydroxystilbene, Res) is a natural polyphenol belonging to the class of stilbenes. Res is a nontoxic phytoalexin synthesized de novo by several plants in response to stress, injury, UV irradiation and pathogen infections (Singh et al., 2015). Resveratrol possesses a wide range of biological properties, among them antioxidative, cardioprotective, neuroprotective, anti-inflammatory, and anticancer (Galiniak et al., 2019; Fan et al., 2009; Duarte et al., 2015). Anticancer properties of resveratrol have been confirmed by many in vitro and in vivo studies, which show that resveratrol is able to inhibit all carcinogenesis stages (i.e., initiation, promotion, and progression) (Varoni et al., 2016; Pezzuto, 2008). Glob- 
ally, many in vitro and animal-based studies have demonstrated preventive anticancer activity in colon, cervical, prostate, breast, and lungs (Zulueta, 2015; Whitlock \& Baek, 2012; Lin et al., 2011).

In the present study, we investigated the influence of resveratrol on PhIP treated human colon cancer cells and compared the effect on $\mathrm{HaCaT}$ cells considered as normal human keratinocytes. Our results show that PhIP-induced apoptosis is caspase $3 / 7$ dependent and normal cells are more resistant to it. Interestingly, while resveratrol decreases DNA damage in both cell types, it increases the sensitivity of LoVo cells to apoptosis and has no effect on PhIP-treated HaCaT cells.

\section{MATERIALS AND METHODS}

Cell lines and the treatment. Human colorectal cancer cell line LoVo (ATCC, USA) and human keratinocyte cell line HaCaT (Cell Lines Service GmbH, Eppelheim, Germany) were cultured in DMEM supplemented with 10\% FBS (Lonza) in a humidified atmosphere at $37^{\circ} \mathrm{C}$ and $5 \% \mathrm{CO}_{2}$ Cells were passaged at c.a. $70-80 \%$ of confluence, and were routinely tested for mycoplasma infection using a PCR-based method. The cells were treated with DMSO or PhIP $(0-100 \mu \mathrm{M})$, resveratrol $(5 \mu \mathrm{M})$ for 6-72 hours. Resveratrol and PhIP were dissolved in DMSO and stored at $-20^{\circ} \mathrm{C}$. Final concentrations of compounds used for different experiments were prepared by diluting the stock with DMEM. Control cultures received the carrier solvent $(0.1 \%$ DMSO).

Comet assay. The level of DNA damage was determined by the electrophoresis of single cells in agarose gel as earlier described (Karabasz et al., 2018). Briefly, the cell suspension was mixed with low melting point agarose, set on slides, lysed and neutralized in appropriate buffers.

Electrophoresis was performed at $23 \mathrm{~V}(0.74 \mathrm{~V} / \mathrm{cm}$, $300 \mathrm{~mA}$ ) for $30 \mathrm{~min}$ at $4^{\circ} \mathrm{C}$. All stages of the experiment were carried out in the dark to avoid any additional DNA damage. Prior to the analysis, the slides were stained with propidium iodide $(2.5 \mu \mathrm{g} / \mathrm{ml})$. The analysis of DNA damage was carried out with COMET PLUS 2.9 software (Comet Plus, Theta System Gmbh, Germany). The percentage content of DNA in the comet's tail (DNA damage) was determined from 100 random images of comets per slide. Each experimental point was run in triplicate.

Cell cytotoxicity and apoptosis assays. For MTT cell viability assay, Thiazolyl Blue Tetrazolium Bromide (MT'T, Sigma) was added for $60 \mathrm{~min}$ at a final concentration of $500 \mathrm{ng} / \mathrm{ml}$. The medium was removed by suction and MTT crystals were dissolved in DMSO: $\mathrm{EtOH}(1: 1)$. The absorbance was measured at $560 \mathrm{~nm}$ a plate reader (Tecan Genios, Männedorf, Switzerland) (Wolnicka-Głubisz et al., 2005).

Caspase $3 / 7$ activity was measured using CaspaseGlo 3/7 Assay (Promega, Madison, USA) as described previously (Skalniak et al., 2018). Combined annexin V/ 7-amino-actinomycin D (7AAD) staining was performed according to the manufacturer's protocol followed by their analysis using a FACScan instrument (BD). All the resulting data was analyzed using the BD Cell Quest pro software (version 5.2.1, BD).

Western blotting. Total cell lysates were prepared with RIPA buffer (Sigma-Aldrich, Missouri, US) containing protease inhibitor cocktail (Sigma-Aldrich, Missouri, US) and PhosSTOP Phosphatase Inhibitor Cocktail (Sigma-Aldrich, Missouri, US). Following the electrophore- sis and transfer, PVDF membranes (Millipore, Billerica, MA, USA) were blocked with $4 \%$ bovine serum albumin (BSA, Sigma-Aldrich, Missouri, US) in TBS-N buffer and incubated with primary antibody at $4^{\circ} \mathrm{C}$ overnight. After three washes, the incubation with secondary antibody ( $1 \mathrm{~h}$ at room temperature) and additional three washes, the detection was performed using Clarity Western ECL Substrate (Bio-Rad, California, USA) with the ChemiDoc (Bio-Rad, California, USA) detector and ImageLab 5.2.1. software.

The following antibodies and dilutions were used: p-Erk1/2, Erk1/2, p21 (1:2 000, Cell Signaling Technology, cat. 9101S, 9102S, 2947S), p53 (1:2 000, SCBt, cat. sc-6243), GAPDH (1:4 000, Cell Signaling Technology, cat. 2118S), goat peroxidase-conjugated anti-rabbit (1:4000, Cell Signaling Technology, cat. 7074), and goat peroxidase-conjugated anti-mouse (1:4000, BP Pharmingen, cat. 554002).

Statistics. All results are the means of at least three independent experiments \pm standard deviation (S.D.). The data was analyzed using Student's $t$-test. The cometassay with one-way ANOVA with Tukey's post-hoc test was applied in Statistica 10 software (StatSoft). Statistical significance was accepted at the level of $p<0.05$.

\section{RESULTS}

\section{Resveratrol reduces PhIP-induced DNA damage but does not affect metabolic activity}

PhIP induced DNA damage in both LoVo (15\% vs. control 6\%) and HaCaT cells (25\% vs. control 6\%) $1 \mathrm{~h}$ after the treatment (Fig. 1A, B) which led to $50 \%$ reduction of metabolic activity measured by MT'T assay $48 \mathrm{~h}$ after the treatment (Fig. 1A, B). Although resveratrol inhibited DNA damage induced by PhIP in the studied cell lines by $26 \%$ and $23 \%$, respectively, it did not increase metabolic activity of PhIP-treated LoVo cells, while it did in HaCaT $24-28 \mathrm{~h}$ after the treatment. Resveratrol used in the present study at a concentration of $5 \mu \mathrm{M}$ had no effect on DNA damage or metabolic activity of any of the cell lines used (Fig. 1A, B).

\section{PhIP induces apoptosis of LoVo cells but not HaCaT}

Caspase $3 / 7$ activity and annexin-V-FITC /7AAD double staining were performed to analyze cell death induced by PhIP in LoVo and HaCaT cells. Figure $2 \mathrm{~A}$ and $\mathrm{C}$ illustrates that $\mathrm{PhIP}$ activated caspase $3 / 7$ in LoVo (by 3 fold), but not in HaCaT cells up to $48 \mathrm{~h}$ following the treatment. Analysis of Annexin VFITC/7AAD-stained cells confirmed the increase of the percentage of apoptotic and necrotic cells among PhIPtreated LoVo cells $(33 \% \pm 5 \%)$, while in $\mathrm{HaCaT}$ cells the effect was much weaker $(9 \pm 2 \%$, Fig. 2D). This was further confirmed by the inhibition of ERK $1 / 2$ phosphorylation, a component in the apoptotic pathway. ERK activity has been associated with markers of apoptosis, like effector caspase-3 activation, poly(ADP-ribose) polymerase (PARP) cleavage, annexin-V staining, and DNA fragmentation (Wang et al., 2000).

\section{PhIP-induced apoptosis is enhanced by resveratrol}

Curcumin reduced PhIP induced apoptosis in MCF-7 cells (Jain et al., 2015), therefore we decided to verify if resveratrol, another polyphenol, has similar or reverse effect on $\mathrm{LoVo}$ and $\mathrm{HaCaT}$ cells. Resveratrol alone had no effect on caspase $3 / 7$ activity, but in the 


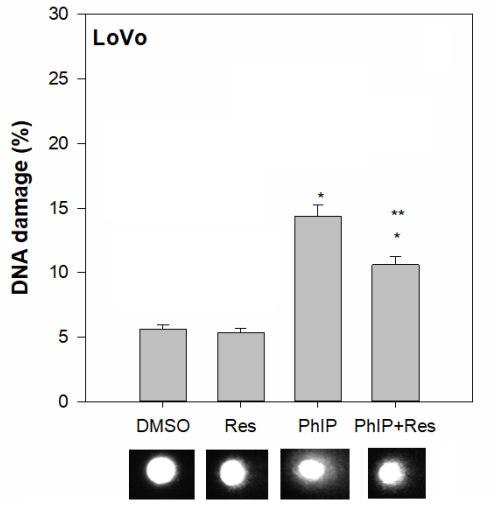

B

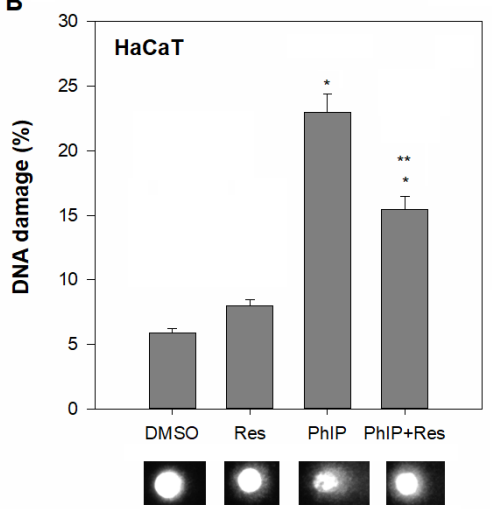

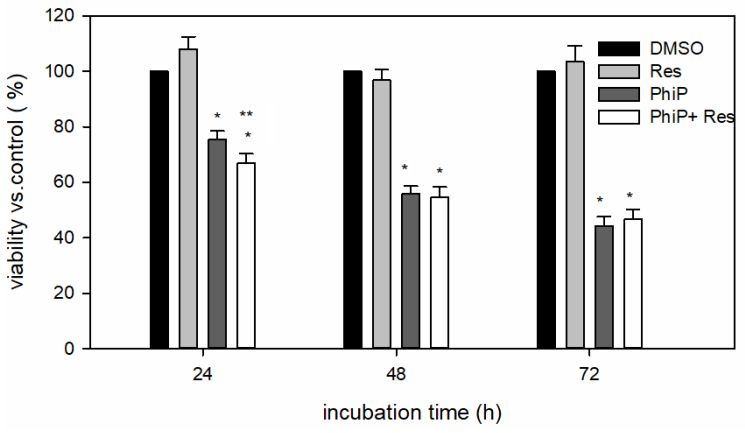

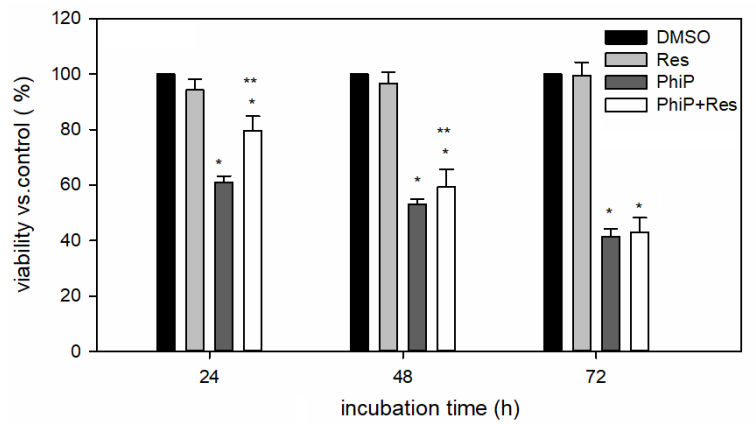

Figure 1. Resveratrol reduced PhIP-induced DNA damage but did not increase the viability of PhIP-treated cells.

DNA damage by comet assay $1 \mathrm{~h}$ after the treatment with PhIP (100 $\mu \mathrm{M}$ ) or/with resveratrol (Res, $5 \mu \mathrm{M})$ (left). MTT assay $24-72 \mathrm{~h}$ after the treatment (right). $1 \mathrm{~A}-$ LoVo cells, $1 \mathrm{~B}-\mathrm{HaCaT}$ cells. The graphs show mean $\pm \mathrm{S} . \mathrm{D}$. from three independent experiments. For the statistics $t$-test was performed: $p<0.05,{ }^{*}$ vs. control (0.1\% DMSO), ${ }^{* *} v s$. PhIP treated cells.

presence of PhIP it induced faster $(6 \mathrm{~h}$ after the treatment) and almost twice as much activation compared to $\mathrm{PhIP}$ alone (24-48 $\mathrm{h}$ after the treatment) in LoVo cells (Fig. 2A). However, PhIP alone or in combination with Res has no significant effect on caspase $3 / 7$ activation in $\mathrm{HaCaT}$ cells (Fig. 2B). Annexin V/7AAD revealed that only in LoVo cells resveratrol enhanced the PhIPinduced apoptosis by about $12 \%$ (Fig. 2C).

ERK $1 / 2$, one of the MAPK, controls both proliferative and apoptotic signals in cells (Schevzov et al., 2015). PhIP decreased phospho-p44/42 MAPK (Erk 1/2) in LoVo by about $50 \%$ and by about $80 \%$ in HaCaT cells (Fig. 3), indicating that PhIP inhibits cell proliferation $48 \mathrm{~h}$ after treatment. The presence of resveratrol had no impact on the PhIP reduced levels of P-ERK 1/2 (Fig. 3).

PhIP alone or in combination with resveratrol increases the expression of p53 in both cell lines $48 \mathrm{~h}$ after the treatment (Fig. 4). This effect is stronger in LoVo cells which are wild-type for p53. HaCaT cell line contains a dysfunctional or only partially functional p53 (Muthusamy \& Piva, 2013). The treatment of LoVo cells with a control compound, idasanutlin (RG7388), led to the increase of p53 level and the level of p21, the protein product of a well-known p53-regulated gene. Although $\mathrm{PhIP}$ alone with or without Res strongly increase level of p53 in LoVo cells, it has no effect on p21 (Fig. 4). We have shown previously that treating $\mathrm{HaCaT}$ cells with idasanutlin, which is a strong inducer of p53 activity, does not lead to an increase of p21 protein (Skalniak et al., 2018). Resveratrol has weak effect on PhIP-induced p53 level.

\section{DISCUSSION}

Resveratrol is known for its antioxidant, chemo preventative, antimutagenic properties (Holme et al., 1989; Martínez Góngora et al., 2019). It is also an inducer of apoptosis in multiple cancer cells (Zhao et al., 2018; Wang et al., 2018; Li et al., 2019). However, the high concentrations that were used in these studies (around $50 \mu \mathrm{M}$ ) are hard to be reached in physiological conditions due to low bioavailability of resveratrol (Almeida et al., 2009; Cottart et al., 2010).

In this work, we investigated the effects of resveratrol on PhIP-treated LoVo and HaCaT cells, as PhIP is a known carcinogenic and mutagenic agent, and both compounds are present in our diet. We use a low concentration of resveratrol $(5 \mu \mathrm{M})$ which itself has no effect on cell viability, metabolic activity or apoptosis and can be achieved physiologically. For example, Boocock et al. showed that after oral administration of $5 \mathrm{~g}$ of resveratrol in blood serum a concentration of $2.4 \mu \mathrm{M}$ was obtained (Boocock et al., 2007). In vitro data showed that a minimum of $5 \mu \mathrm{M}$ resveratrol is required for the chemo preventive effects to be elicited (Boocock et al., 2007).

Previous reports have shown that human CYP1A2 is particularly efficient to metabolically process PhIP to toxic species, such as N-hydroxy derivatives. Subsequent metabolic esterification generates potent DNA damag- 

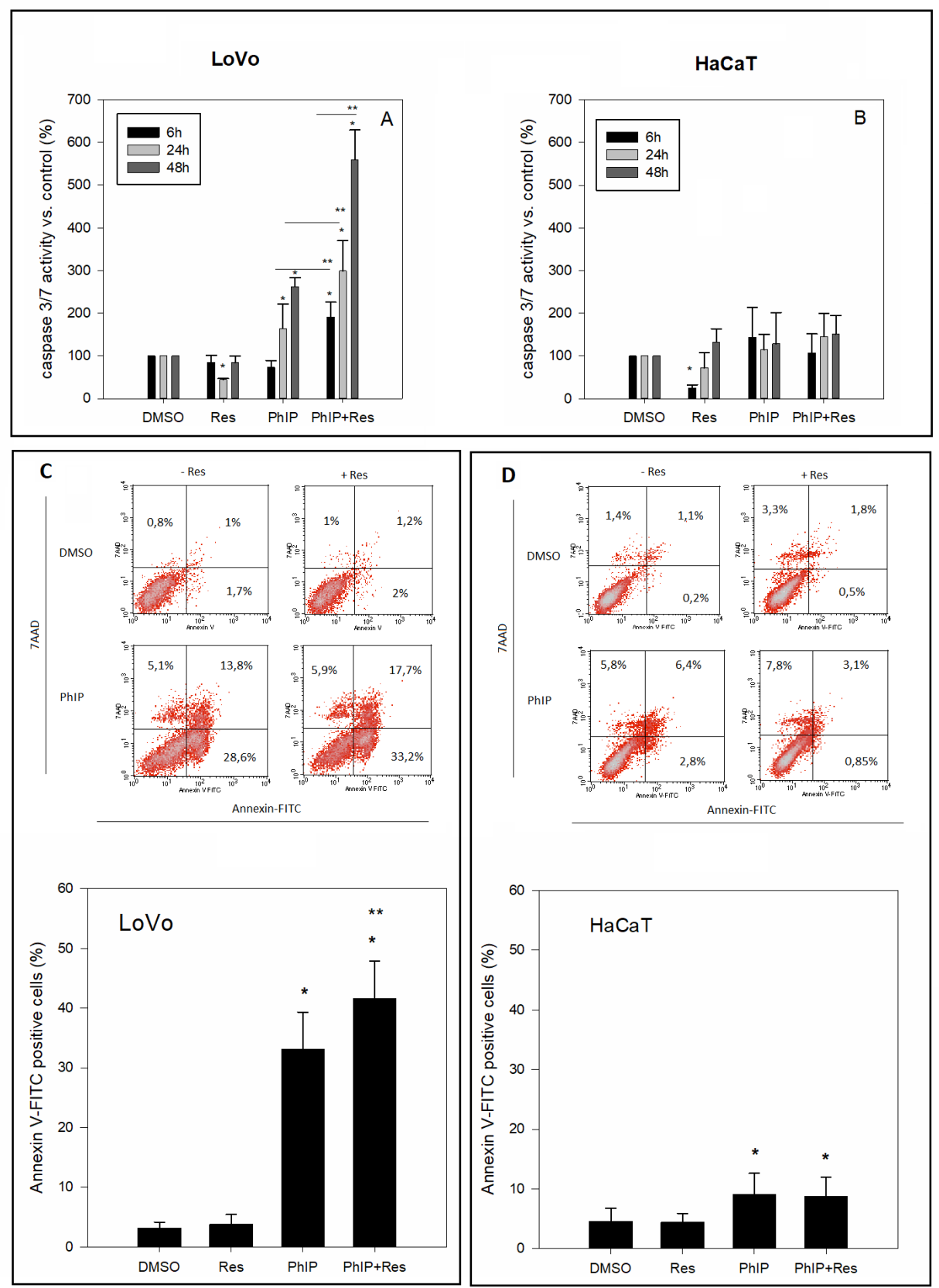

Figure 2. PhIP induced apoptosis in LoVo cells but not in HaCaT cells. Caspase $3 / 7$ activity at 6,24 and $48 \mathrm{~h}$ after the treatment (A, B). Annexin V-FITC/7AAD double staining of cells (C, D). Graphs represent mean values of three independent experiments \pm S.D.

ing species (Buonarati et al., 1990) which are responsible for single and double DNA strain breaks detected in the comet assay. We found that DNA damage is more pronounced in $\mathrm{HaCaT}$ ( $25 \%$ of DNA in comet tails) than LoVo cells $(15 \%)$ which may suggest higher level of CYP1A2 in these cells. Although the main mechanisms by which PhIP induced DNA damage is adduct formation, the role of reactive oxygen (ROS) cannot be excluded.

As previously indicated, $10 \mu \mathrm{M}$ resveratrol attenuates the mutagenicity of PhIP in hamster V79 cells (Boyce et al., 2004). Dubuisson showed that $50 \mu \mathrm{M}$ resveratrol decreases the PhIP DNA adducts by $31-69 \%$ in primary cultures of human mammary epithelial cells and suppressed $O$-acetyltransferase and sulfotransferase activities in the breast cancer cell lines MCF-7 and ZR75-1 (Dubuisson et al., 2002). We confirmed that PhIP induces DNA damage within the hour after the treatment. In our study, addition of $5 \mu \mathrm{M}$ resveratrol inhibits PhiP-induced DNA damage by about $25 \%$ in both cell lines.

PhIP $(100 \mu \mathrm{M})$ induced a higher level of DNA damage in $\mathrm{HaCaT}$ and a higher percentage of metabolically inactive cells $24 \mathrm{~h}$ after the treatment, but the viability of the $\mathrm{LoVO}_{\mathrm{O}}$ and $\mathrm{HaCaT}$ cells $48 \mathrm{~h}$ after the treatment remains similar $(50 \%)$, which may suggest that $\mathrm{HaCa}$ T cells repair their DNA faster or have a more efficient detoxification activity (4-OH PhIP derivative) than LoVo, which could be worth verifying. Resveratrol had no effect on untreated and PhIPtreated LoVo cells but slightly increased viability of PhIP-treated HaCaT cells, measured by MT'T assay. The decrease of viability induced by PhIP was accom- 


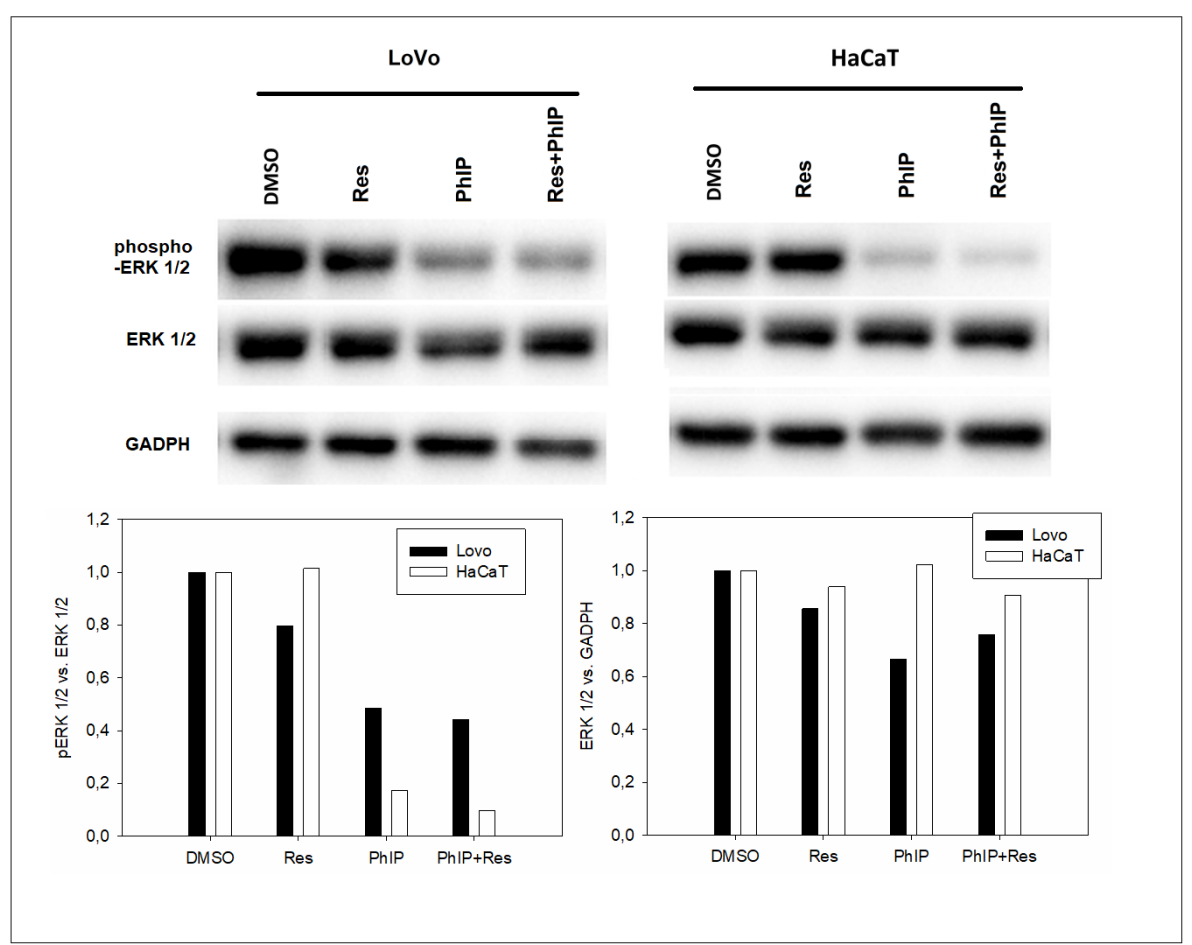

Figure 3. PhIP decreases ERK $1 / 2$ activation.

The expression of indicated protein by western blot $48 \mathrm{~h}$ after the treatment with PhIP $(100 \mu \mathrm{M})$, resveratrol (Res; $5 \mu \mathrm{M})$, or both (PhIP+Res).
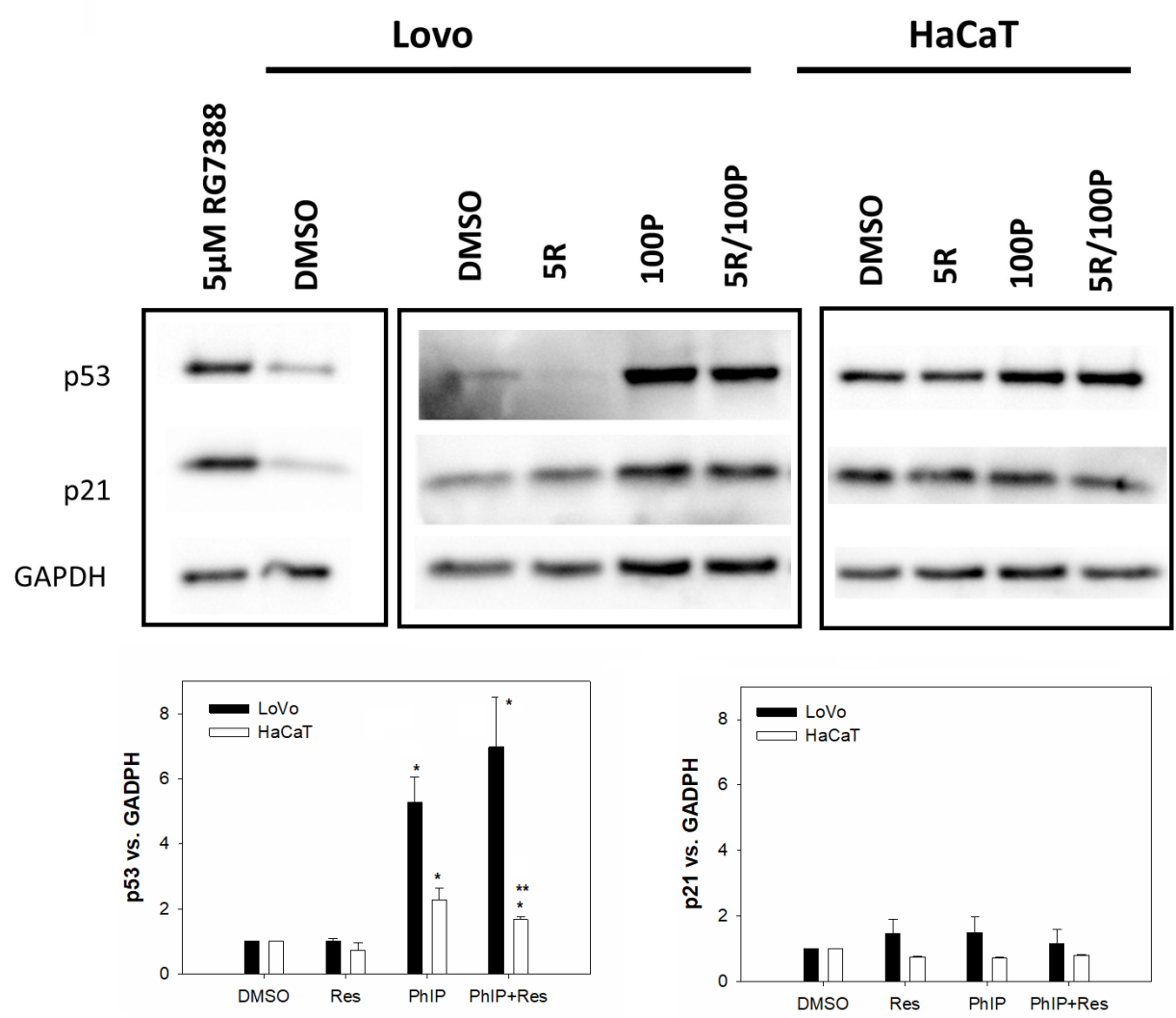

Figure 4. Expression of p53 and p21 $48 \mathrm{~h}$ after the treatment with PhIP (100 $\mu \mathrm{M})$, resveratrol (Res; $5 \mu \mathrm{M})$ or both (PhIP+Res), as shown by the western blot analysis.

Positive control - RG7388 (5 $\mu \mathrm{M}$ for $6 \mathrm{~h}$ ). The graph shows means \pm S.E. from three independent experiments, presented as fold change versus control. For the statistics the $t$-test was performed: $\mathrm{P}<0.05,{ }^{*} v s$. control (DMSO), ${ }^{* *} v s$. PhIP. 
panied by an inhibition of ERK $1 / 2$ phosphorylation, a decrease in ERK, and an increase in apoptosis. Resveratrol has no effect on ERK $1 / 2$ activation in LoVo or $\mathrm{HaCaT}$ cells, neither treated nor untreated. Annexin $\mathrm{V}$ staining of PhIP -treated cells revealed higher percentage of Annexin V+ in LoVo cells (42\%) than in $\mathrm{HaCaT}$ cells $(10 \%)$. Interestingly, resveratrol increases percentage of Annexin $\mathrm{V}$ in LoVo cells up to $50 \%$ but has weak effect on $\mathrm{HaCaT}$, suggesting the involvement of various pathways.

It has previously been shown that PhIP induced DNA damage is p53 dependent in mice (Krais et al., 2016), and that PhIP leads to apoptosis via p53/p21 pathway in MCF-10A, which is induced by DNA damage (Gooderham et al., 2007). The tumor suppressor p53 is a multifunctional transcription factor that drives the expression of genes for growth arrest, DNA repair, senescence, and apoptosis (Oren, 2003). Indeed, we found p53 increase level $48 \mathrm{~h}$ after treatment in PhIP treated cells but not at earlier time points. $\mathrm{HaCaT}$ cells lack functional p53/p21 signaling (Skalniak et al., 2018) what could explain their resistance to PhIP-induced apoptosis if this is the only mechanism. LoVo cells are wild-type for p53 and have a functional p53/p21 signaling what we have confirmed using RG 7388, an MDM2 antagonist. However, we did not detect any changes in p21 level up to $72 \mathrm{~h}$, which may suggest that p53 activates the transcription of pro-apoptotic genes other than p21WAF1 in these cells or that a second pathway is activated in which p53 activates the transcription of TNF-receptor family, which requires verification. The binding of a ligand to its cognate receptor initiates this pathway through the formation of the death-inducing signaling complex that activates the initiator caspase- 8 , which proceeds to activate the effector caspase- 3 and -7 to induce apoptosis (Guicciardi \& Gores, 2009). Indeed, we found activation of caspase $3 / 7$ in LoVo but not in HaCaT cells 24-48 h after PhIP treatment.

Interestingly, the presence of resveratrol induced faster (upon $6 \mathrm{~h}$ ) and significantly stronger caspase $3 / 7$ activation in LoVo cells and has no effect on caspase 3/7 activation in $\mathrm{HaCa}$ T cells.

Our studies may suggest that diet rich in resveratrol could protect an organism from PhIP induced mutagenic effects by reducing DNA-induced damage and directing of cancer cells to apoptosis, and increasing normal cells viability. However this conclusion requires further verification in in vivo model.

\section{Acknowledgment}

Faculty of Biochemistry, Biophysics and Biotechnology, Jagiellonian University is a partner of the leading National Research Center (KNOW) supported by the Ministry of Science and Higher Education, Poland.

\section{Conflict of interest statement}

The authors do not declare any conflict of interest associated with this manuscript

\section{REFERENCES}

Almeida L, Vaz-da-Silva M, Falcão A, Soares E, Costa R, Loureiro AI, Fernandes-Lopes C, Rocha J-F, Nunes T, Wright L, Soares-da-Silva P (2009) Pharmacokinetic and safety profile of trans-resveratrol in a rising multiple-dose study in healthy volunteers. Mol. Nutr. Food Res. 53: S7-S15. https://doi.org/10.1002/mnfr.200800177

Boocock DJ, Faust GES, Patel KR, Schinas AM, Brown VA, Ducharme MP, Booth TD, Crowell JA, Perloff M, Gescher AJ, Steward
WP, Brenner DE (2007) Phase I dose escalation pharmacokinetic study in healthy volunteers of resveratrol, a potential cancer chemopreventive agent. Cancer Epidemiol. Biomarkers Prev. 16: 1246-1252. https://doi.org/10.1158/1055-9965.EPI-07-0022

Boyce A, Doehmer J, Gooderham NJ (2004) Phytoalexin resveratrol attenuates the mutagenicity of the heterocyclic amines 2-amino1-methyl-6-phenylimidazo[4,5-b]pyridine and 2-amino-3,8-dimethylimidazo[4,5-f]quinoxaline. J. Chromatogr. B 802: 217-223. https:// doi.org/10.1016/j.jchromb.2003.10.057

Buonarati MH, Turteltaub KW, Shen NH, Felton JS (1990) Role of sulfation and acetylation in the activation of 2-hydroxyamino1-methyl-6-phenylimidazo[4,5-b]pyridine to intermediates which bind DNA. Mutat. Res. 245: 185-90. https://doi.org/10.1016/01657992(90)90048-o

Chan DSM, Lau R, Aune D, Vieira R, Greenwood DC, Kampman E, Norat T (2011) Red and processed meat and colorectal cancer incidence: meta-analysis of prospective studies. PLoS One 6: e20456. https://doi.org/10.1371/journal.pone.0020456

Cottart C-H, Nivet-Antoine V, Laguillier-Morizot C, Beaudeux J-L (2010) Resveratrol bioavailability and toxicity in humans. Mol. Nutr. Food Res. 54: 7-16. https://doi.org/10.1002/mnfr.200900437

Cross AJ, Freedman ND, Ren J, Ward MH, Hollenbeck AR, Schatzkin A, Sinha R, Abnet CC (2011) Meat consumption and risk of esophageal and gastric cancer in a large prospective study. Am. J. Gastroenterol. 106: 432-442. https://doi.org/10.1038/ajg.2010.415

Daniel CR, Cross AJ, Graubard BI, Park Y, Ward MH, Rothman N, Hollenbeck AR, Chow W-H, Sinha R (2012) Large prospective investigation of meat intake, related mutagens, and risk of renal cell carcinoma. Am. J. Clin. Nutr. 95: 155-162. https://doi.org/10.3945/ ajcn.111.019364

Duarte A, Martinho A, Luís Â, Figueiras A, Oleastro M, Domingues FC, Silva F (2015) Resveratrol encapsulation with methyl- $\beta$ cyclodextrin for antibacterial and antioxidant delivery applications. LWT - Food Sci. Technol. 63: 1254-1260. https://doi.org/10.1016/j. lwt.2015.04.004

Dubuisson JG, Dyess DL, Gaubatz JW (2002) Resveratrol modulates human mammary epithelial cell O-acetyltransferase, sulfotransferase, and kinase activation of the heterocyclic amine carcinogen N-hydroxy-PhIP. Cancer Lett. 182: 27-32. https://doi.org/10.1016/ S0304-3835(02)00061-7

Fan P, Marston A, Hay A-E, Hostettmann K (2009) Rapid separation of three glucosylated resveratrol analogues from the invasive plant Polygonum cuspidatum by high-speed countercurrent chromatography. J. Sep. Sci. 32: 2979-2984. https://doi.org/10.1002/jssc.200900057

Ferrucci LM, Sinha R, Huang W-Y, Berndt SI, Katki HA, Schoen RE, Hayes RB, Cross AJ (2012) Meat consumption and the risk of incident distal colon and rectal adenoma. Br. J. Cancer 106: 608-616. https://doi.org/10.1038/bjc.2011.549

Galiniak S, Aebisher D, Bartusik-Aebisher D (2019) Health benefits of resveratrol administration. Acta Biochim. Pol. https://doi. org/10.18388/abp.2018_2749

Gooderham NJ, Creton S, Lauber SN, Zhu H (2007) Mechanisms of action of the carcinogenic heterocyclic amine PhIP. Toxicol. Lett. 168: 269-277. https://doi.org/10.1016/j.toxlet.2006.10.022

Guicciardi ME, Gores GJ (2009) Life and death by death receptors. FASEB J. 23: 1625-1637. https://doi.org/10.1096/fj.08-111005

Holme JA, Wallin H, Brunborg G, Søderlund EJ, Hongslo JK, Alexander J (1989) Genotoxicity of the food mutagen 2-amino-1-methyl6-phenylimidazo[4,5-b]pyridine (PhIP): formation of 2-hydroxamino-PhIP, a directly acting genotixic metabolite. Carcinogenesis 10: 1389-1396. https://doi.org/10.1093/carcin/10.8.1389

Jain A, Samykutty A, Jackson C, Browning D, Bollag WB, Thangaraju M, Takahashi S, Singh SR (2015) Curcumin inhibits PhIP induced cytotoxicity in breast epithelial cells through multiple molecular targets. Cancer Lett. 365: 122-131. https://doi.org/10.1016/j.canlet.2015.05.017

Karabasz A, Szczepanowicz K, Cierniak A, Bereta J, Bzowska M (2018) In vitro toxicity studies of biodegradable, polyelectrolyte nanocapsules. Int. J. Nanomedicine 13: 5159-5172. https://doi.org/10.2147/ IJN.S169120

Kim J, Park S, Nam B-H (2011) The risk of colorectal cancer is associated with the frequency of meat consumption in a population-based cohort in Korea. Asian Pac. J. Cancer Prev. 12: 2371-2376.

Krais AM, Speksnijder EN, Melis JPM, Singh R, Caldwell A, Gamboa da Costa G, Luijten M, Phillips DH, Arlt VM (2016) Metabolic activation of 2-amino-1-methyl-6-phenylimidazo [4,5-b]pyridine and DNA adduct formation depends on p53: Studies in $\mathrm{T}$ rp53 $(+/+)$, $\mathrm{T}$ rp53 (+/-) and $\mathrm{T}$ rp53 (-/-) mice. Int. J. Cancer 138: 976-982. https://doi.org/10.1002/ijc.29836

Li D, Wang G, Jin G, Yao K, Zhao Z, Bie L, Guo Y, Li N, Deng W, Chen X, Chen B, Liu Y, Luo S, Guo Z (2019) Resveratrol suppresses colon cancer growth by targeting the AKT/STAT3 signaling pathway. Int. J. Mol. Med. 43: 630-640. https://doi.org/10.3892/ ijmm.2018.3969 
Lin H-Y, Tang H-Y, Davis FB, Davis PJ (2011) Resveratrol and apoptosis. Ann. N. Y. Acad. Sci. 1215: 79-88. https://doi.org/10.1111/ j.1749-6632.2010.05846.x

Manabe S, Tohyama K, Wada O, Aramaki T (1991) Detection of a carcinogen, 2-amino-1-methyl-6-phenylimidazo [4,5- b ]pyridine $(\mathrm{PhIP})$, in cigarette smoke condensate. Carcinogenesis 12: 1945-1947. https://doi.org/10.1093/carcin/12.10.1945

Martínez Góngora V, Matthes KL, Castaño PR, Linseisen J, Rohrmann S (2019) Dietary heterocyclic amine intake and colorectal adenoma risk: a systematic review and meta-analysis. Cancer Epidemiol. Biomarkers Prev. 28: 99-109. https://doi.org/10.1158/1055-9965.EPI17-1017

Muthusamy V, Piva TJ (2013) A comparative study of UV-induced cell signalling pathways in human keratinocyte-derived cell lines. Arch. Dermatol. Res. 305: 817-833. https://doi.org/10.1007/s00403-0131412-z

Oren M (2003) Decision making by p53: life, death and cancer. Cell Death Differ. 10: 431-442. https://doi.org/10.1038/si.cdd.4401183

Pezzuto JM (2008) Resveratrol as an inhibitor of carcinogenesis. Pharm. Biol. 46: 443-573. https://doi.org/10.1080/13880200802116610

Puangsombat K, Gadgil P, Houser TA, Hunt MC, Smith JS (2012) Occurrence of heterocyclic amines in cooked meat products. Meat Sci. 90: 739-746. https://doi.org/10.1016/j.meatsci.2011.11.005

Robbana-Barnat S, Rabache M, Rialland E, Fradin J (1996) Heterocyclic amines: occurrence and prevention in cooked food. Environ Health Perspect. 104: 280-288. https://doi.org/10.1289/ehp.96104280

Rohrmann S, Hermann S, Linseisen J (2009) Heterocyclic aromatic amine intake increases colorectal adenoma risk: findings from a prospective European cohort study. Am. J. Clin. Nutr. 89: 1418-1424. https://doi.org/10.3945/ajcn.2008.26658

Schevzov G, Kee AJ, Wang B, Sequeira VB, Hook J, Coombes JD, Lucas CA, Stehn JR, Musgrove EA, Cretu A, Assoian R, Fath T, Hanoch T, Seger R, Pleines I, Kile BT, Hardeman EC, Gunning PW (2015) Regulation of cell proliferation by ERK and signal-dependent nuclear translocation of ERK is dependent on Tm5NM1containing actin filaments. Mol. Biol. Cell 26: 2475-2490. https://doi. org/10.1091/mbc.E14-10-1453

De Silva A, Lanerolle P (2011) Nutraceuticals: concepts and controversies. Ceylon Med. J. 56: 171. https://doi.org/10.4038/cmi.v56i4.3901

Singh CK, Ndiaye MA, Ahmad N (2015) Resveratrol and cancer: Challenges for clinical translation. Biochim. Biophys. Acta-Mol. Basis Dis. 1852: 1178-1185. https://doi.org/10.1016/j.bbadis.2014.11.004

Sinha R, Chow WH, Kulldorff M, Denobile J, Butler J, Garcia-Closas M, Weil R, Hoover RN, Rothman N (1999) Well-done, grilled red meat increases the risk of colorectal adenomas. Cancer Res. 59: 4320-4324
Skalniak L, Smejda M, Cierniak A, Adamczyk A, Konieczny P, Madej E, Wolnicka-Glubisz A (2018) p38 but not p53 is responsible for UVA-induced MCPIP1 expression. Mech. Ageing Dev. 172: 96-106. https://doi.org/10.1016/j.mad.2017.11.008

Skog K, Steineck G, Augustsson K, Jägerstad M (1995) Effect of cooking temperature on the formation of heterocyclic amines in fried meat products and pan residues. Carcinogenesis 16: 861-867. https:// doi.org/10.1093/carcin/16.4.861

Sugimura T (1997) Overview of carcinogenic heterocyclic amines. $M u$ tat. Res. Mol. Mech. Mutagen. 376: 211-219. https://doi.org/10.1016/ S0027-5107(97)00045-6

Varoni EM, Lo Faro AF, Sharifi-Rad J, Iriti M (2016) Anticancer Molecular Mechanisms of Resveratrol. Front. Nutr. 3: 8. https://doi. org/10.3389/fnut.2016.00008

Wang D, Gao Z, Zhang X (2018) Resveratrol induces apoptosis in murine prostate cancer cells via hypoxia-inducible factor 1-alpha $(\mathrm{HIF}-1 \alpha) /$ reactive oxygen species (ROS)/P53 signaling. Med. Sci. Monit. 24: 8970-8976. https://doi.org/10.12659/MSM.913290

Wang X, Martindale JL, Holbrook NJ (2000) Requirement for ERK activation in cisplatin-induced apoptosis. J. Biol. Chem. 275: 3943539443. https://doi.org/10.1074/jbc.M004583200

Whitlock NC, Baek SJ (2012) The anticancer effects of resveratrol: modulation of transcription factors. Nutr. Cancer 64: 493-502. https://doi.org/10.1080/01635581.2012.667862

Wolnicka-Głubisz A, Rajwa B, Dobrucki J, Skrzeczyńska-Moncznik J, van Henegouwen GB, Sarna T (2005) Phototoxicity, distribution and kinetics of association of UVA-activated chlorpromazine, 8-methoxypsoralen, and 4,6,4'-trimethylangelicin in Jurkat cells. J. Photochem. Photobiol. B Biol. 78: 155-164. https://doi.org/10.1016/j. jphotobiol.2004.11.002

World Cancer Research Fund/American Institute for Cancer Research (2007) Food, Nutrition, Physical Activity, and the Prevention of Cancer: A Global Perspective. Washington, DC Am Inst Cancer Res

Zandonai AP, Sonobe HM, Sawada NO (2012) Os fatores de riscos alimentares para câncer colorretal relacionado ao consumo de carnes. Rev. da Esc. Enferm. da USP 46: 234-239. https://doi.org/10.1590/ S0080-62342012000100031

Zhao H, Han L, Jian Y, Ma Y, Yan W, Chen X, Xu H, Li L (2018) Resveratrol induces apoptosis in human melanoma cell through negatively regulating Erk/PKM2/Bcl-2 axis. Onco. Targets. Ther. 11: 8995-9006. https://doi.org/10.2147/OT'T.S186247

Zulueta A (2015) Resveratrol: A potential challenger against gastric cancer. World J. Gastroenterol. 21: 10636. https://doi.org/10.3748/ wjg.v21.i37.10636 